\title{
PUBLISHER CORRECTION OPEN Publisher Correction: npj Vaccines, volume 4
}

\author{
npj Vaccines ${ }^{1}$ \\ npj Vaccines (2019)4:36; https://doi.org/10.1038/s41541-019-0127-3
}

An error occurred during the publication of a number of articles in npj Vaccines. Several articles were published in volume 4 with a duplicate citation number.

In this correction article the old and new citation metadata are published in Table 1.

The original articles have been updated. The publisher apologises for the inconvenience caused to our authors and readers.

\begin{abstract}
Open Access This article is licensed under a Creative Commons Attribution 4.0 International License, which permits use, sharing, adaptation, distribution and reproduction in any medium or format, as long as you give appropriate credit to the original author(s) and the source, provide a link to the Creative Commons license, and indicate if changes were made. The images or other third party material in this article are included in the article's Creative Commons license, unless indicated otherwise in a credit line to the material. If material is not included in the article's Creative Commons license and your intended use is not permitted by statutory regulation or exceeds the permitted use, you will need to obtain permission directly from the copyright holder. To view a copy of this license, visit http://creativecommons. org/licenses/by/4.0/.
\end{abstract}

(c) The Author(s) 2019

Table 1. Overview of incorrect and correct citation metadata

\begin{tabular}{llll}
\hline DOI & Published online date & Incorrect citation number & Correct citation number \\
\hline $10.1038 /$ s41541-019-0117-5 & 03 June 2019 & 1 & 25 \\
$10.1038 /$ s41541-019-0118-4 & 03 June 2019 & 2 & 26 \\
$10.1038 /$ s41541-019-0119-3 & 25 June 2019 & 3 & 27 \\
\hline
\end{tabular}

${ }^{1}$ London, United Kingdom

Correspondence: npj Vaccines (npjvaccines@nature.com)

Published online: 13 August 2019 